\title{
UCLA
}

\section{K-12 Integration and Diversity}

Title

Deepening Segregation in American Public Schools: A Special Report from the Harvard Project on School Desegregation

\section{Permalink}

https://escholarship.org/uc/item/22z7v7ms

\section{Authors}

Orfield, Gary

Bachmeier, Mark D

James, David R

et al.

\section{Publication Date}

1997-09-01

Peer reviewed 


\title{
Deepening Segregation in American Public Schools: A Special Report from the Harvard Project on School Desegregation
}

\author{
GARY ORFIELD, MARK D. BACHMEIER, DAVID R. JAMES, \\ and TAMELA EITLE
}

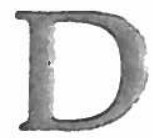

ecades of legal and political struggle were required to end the apartheid system of mandated segregation in the schools of 17 states and to transform the South from an area of absolute segregation for black students to the most integrated region of the country. We often celebrate this accomplishment as if it were a permanent reversal of a history of segregation and inequality. From the 1950 s through the late 1980s, African American students experienced declining segregation, particularly in the southern and border states.

The changes begun by the 1954 Supreme Court decision in Brown v. Board of Education, however, are now coming undone. The statistics analyzed for this article show that segregation is increasing for blacks, particularly in the states that once mandated racial separation. For Latinos, an even more severe level of segregation is intensifying across the nation.

The trends reported here are the first since the Supreme Court, in the 1990 s, approved a return to segregated neighborhood schools under some conditions. A number of major cities have recently received court approval for such changes and others are in court. The segregation changes reported here are most striking in the southern and border states, but segregation is spreading across the nation, particularly affecting our rapidly growing Latino communities in the West. This report shows that the racial and ethnic segregation of African American and Latino students has produced a deepening isolation from middle-class students and from successful schools. It also highlights a little noticed but extremely important expansion of segregation to the suburbs, particularly in larger metropolitan areas. Expanding segregation is a mark of a polarizing society that lacks effective policies for building multiracial institutions.

Latino students, who will soon be the largest minority group in American public schools, were granted the right to desegregated education by the Supreme Court in 1973, but new data show they now are significantly more segregated than black students, with clear evidence of increasing isolation across the nation. Part of this trend is caused by the very rapid growth in the number of Latino students in several major states. Regardless of the reasons, Latino students now experience more isolation from whites and more concentration in high poverty schools than any other group of students. 1,2

Desegregation is not just sitting next to someone of another race. Economic class and family and community educational background are also critically important for educational opportunity. School segregation effects go beyond racial separation. Segregated black and Latino schools are fundamentally different from segregated white schools in terms of the background of the children and many things that relate to educational quality. This report shows that only a twentieth of the nation's segregated white schools face conditions of concentrated poverty among their children, but more than $80 \%$ of segregated black and Latino schools do. A child moving from a segregated African American or Latino school to a white school will very likely exchange conditions of concentrated poverty for a middle-class school. Exactly the opposite is likely when a child is sent back from an interracial school to a segregated neighborhood school, as is happening under a number of recent court orders that end busing or desegregation choice plans.

The Supreme Court concluded in 1954 that intentionally segregated schools were "inherently unequal," and contemporary evidence indicates that this remains true today. Thus, it is very important to continuously monitor the extent to which the nation is realizing the promise of equal educational opportunity in schools that are now racially segregated. Education was vital to the success of the black tenth of the U.S. population when de jure segregation was declared unconstitutional-it is far more important today, when millions of good, low-edu- 
cation jobs have vanished, and when one-third of public school students are non-white. ${ }^{3}$

With the stakes for educational opportunity much higher today, this report shows that we are moving backward toward greater racial separation, rather than pressing gradually forward as we were between the 1950s and the mid-1980s. It shows a delayed impact of the Reagan administration campaign to reverse desegregation orders, which made no progress while Reagan was president, but now has had a substantial impact through appointments that transformed the federal courts. The 1991-95 period following the Supreme Court's first decision authorizing resegregation witnessed the continuation of the largest backward movement toward segregation for blacks in the 43 years since Brown.

During the 1980s, the courts rejected efforts to terminate school desegregation, and the level of desegregation actually increased, although the Reagan and Bush administrations advocated reversals. Congress rejected proposals for major steps to reverse desegregation, and there has been no trend toward increasing hostility to desegregation in public opinion. In fact, opinion is becoming more favorable. 4 The policy changes have come from the courts. The Supreme Court, in decisions from 1991 to 1995, has given lower courts discretion to approve resegregation on a large scale, and it is beginning to occur.

The statistics reported here show only the first phase of what is likely to be an accelerating trend. These statistics for the 1994-95 school year do not reflect post-1994 decisions that terminated desegregation plans in metropolitan Wilmington, Broward County (Florida), Denver, Buffalo, Mobile, Cleveland, and a number of other areas. Important cases in several other cities are pending in court now. These decisions are virtually certain to accelerate the trend toward increased racial and economic segregation of African American and Latino students. Thus, the trends reported today should be taken as portents of larger changes now under way.

\section{BACKGROUND OF DESEGREGATION}

In 1954 the Supreme Court began the process of desegregating American public education in its landmark decision, Brown v. Board of Education. Congress took its most powerful action for school desegregation with the passage of the 1964 Civil Rights Act. In 1971, the great national battle over urban desegregation began with the Supreme Court's decision in the Charlotte, North Carolina, busing case, Swann v. Charlotte-Mecklenberg Board of Education. 5 With Swann, there was a comprehensive set of policies in place for massive desegregation in the South.

No similar body of law ever developed in the North and West. The Supreme Court first extended some desegregation requirements to the cities of the North and recognized the rights of Hispanic as well as black students from illegal segregation in 1973.6 In the early 1970 s Congress enacted legislation to help pay for the training and educational changes (but not the busing) needed to make desegregation more effective. These last major initiatives intended to foster desegregation took place more than two decades ago.

Since 1974 almost all of the federal policy changes have been negative, even while the nation's non-white population has dramatically increased, particularly its school age children. In what is rapidly becoming a society dominated by suburbia, only a small fraction of white middle-class children are growing up in central cities. The key Supreme Court decision of Milliken $v$. Bradley 7 in 1974 reversed lower court plans to desegregate metropolitan Detroit and provided a drastic limitation on the possibility of substantial and lasting city-suburban school desegregation. That decision ended significant movement toward less segregated schools and made desegregation virtually impossible in many metropolitan areas where the non-white population was concentrated in central cities. (It is not, therefore, surprising that the state of Michigan ranks second in the nation in segregation of black students two decades after the Supreme Court confined desegregation efforts within the boundaries of a largely black and economically declining city. $)^{8}$

The Supreme Court ruled that the courts could try to make segregated schools more equal in its second Detroit decision in 1977, Milliken v. Bradley II.9 The Court authorized an order that the State of Michigan pay for some needed programs in Detroit which were aimed at repairing the harms inflicted by segregation in schools that would remain segregated because of the 1974 decision blocking city-suburban desegregation. Unfortunately, there was little serious follow-up by the courts on the educational remedies, and the Supreme Court severely limited such remedies in the 1995 Missouri $v$. Jenkins ${ }^{10}$ decision.

The government turned actively against school desegregation in 1981 under the Reagan administration, with the Justice Department reversing policy on many pending cases and attacking urban desegregation orders. Congress accepted the administration's proposal to end the federal desegregation assistance program in the 1981 Omnibus Budget Reconciliation Act. Twelve years of active efforts to reverse desegregation orders and remake the federal courts followed. The Clinton administration in its first term defended some orders but developed no coherent policy and took no significant initiatives for desegregation.

By far the most important changes in policy have come from the Supreme Court. The appointment of Justice Clarence Thomas in 1991 consolidated a majority favoring cutting back civil rights remedies requiring 
court-ordered changes in racial patterns. In the 1991 Board of Education of Oklahoma City v. Dowell'1 decision, the Supreme Court ruled that a school district that had complied with its court order for several years could be allowed to return to segregated neighborhood schools if it met specific conditions. In the 1992 Freeman $v$. Pitts ${ }^{12}$ decision, the Court made it easier to end student desegregation even when the other elements of a full desegregation order had never been accomplished. Finally, in its 1995 Jenkins decision, the Court's majority ruled that the court-ordered programs designed to make segregated schools more equal educationally and to increase the attractiveness of the schools to accomplish desegregation through voluntary choices were temporary and did not have to work before they could be discontinued.

In other words, desegregation was redefined from the goal of ending schools defined by race to a temporary and limited process that created no lasting rights and need not overcome the inequalities growing out of a segregated history. These decisions stimulated efforts in a number of cities to end the court orders, sometimes even over the objection of the school district involved.

\section{RACIAL COMPOSITION OF AMERICAN SCHOOLS}

As the courts were cutting back on desegregation requirements, the proportion of minority students in public schools was growing rapidly and becoming far more diverse. In the fall of 1994, American public schools enrolled more than 43 million students, of whom $66 \%$ were white, $17 \%$ African American, $13 \%$ Latino, $4 \%$ Asian, and $1 \%$ Indian and Alaskan. The proportion of Latinos in the United States was higher than that of blacks at the time desegregation began in 1954, and the proportion of whites was far lower. The two regions with the largest school enrollments, the South and the West, were $58 \%$ and $57 \%$ white, foreshadowing a near future in which large regions of the United States would have white mi-

Toble :

Public School Enrollment Changes, 1968-94 (in Millions)

\begin{tabular}{|l|r|r|r|c|}
\hline & 1968 & 1980 & 1994 & $\begin{array}{c}\text { Chonge } \\
1968-94\end{array}$ \\
\hline Hispanics & 2.00 & 3.18 & 5.57 & $+3.57(178 \%)$ \\
Anglos & 34.70 & 29.16 & 28.46 & $-6.24(-18 \%)$ \\
Blacks & 6.28 & 6.42 & 7.13 & $+0.85(14 \%)$ \\
\hline
\end{tabular}

Source: DBS Corp., 1982, 1987: Gary Orfield Rosemary George, and Amy Orfield. "Racial Change in U.S. School Enrollments. 1968-1984." paper presented af National Conference on School Desegregation. University of Chicago. 1968. 1994-95 NCES Common Core of Datc norities. Table 1 shows that there has been a huge growth $(178 \%)$ in the number of Latino students during the 26 years since 1968, when data was first available nationally, to 1994. Meanwhile, the number of white (Anglo) students declined $9 \%$, and the number of black students rose $14 \%$.

On a regional level, African Americans remained the largest minority group in the schools of all regions except the West and Alaska and Hawaii. The proportion of black students in the South was, however, about twice the proportion in the Northeast and Midwest and more than four times the level in the West. Latinos, on the other hand, made up more than a fourth of the enrollment in the West but only about a 50th in the Border region and a 25th in the Midwest (Table 2).

The dramatic changes in the composition of American school enrollment is most apparent in five states that already have a majority of non-white students statewide. These include the nation's two most populous states, California and Texas, which enroll 8.8 million students and are both moving rapidly toward a Latino majority in their school systems (Table 3).

\section{NATIONAL INCREASE IN SEGREGATION}

In the fall of 1972, after the Supreme Court's 1971 busing decision that led to new court orders for scores of school districts, $63.6 \%$ of black students were in schools with less than half white enrollment. Fourteen years later, that percentage was virtually the same, but it rose to $67.1 \%$ by $1994-95$ (Table 4). Desegregation remained at its high point until about 1988 but then began to fall significantly on this measure.

A second measure of segregation, calculated as the number of students experiencing intense isolation in schools with less than one-tenth whites (i.e., 90-100\% minority enrollment), shows that the proportion of black students facing extreme isolation dropped sharply with the busing decisions, declining from $64.3 \%$ in 1968 to $38.7 \%$ in 1972 and continuing to decline slightly through the mid-1980s (Table 4). This isolation increased gradually from 1988 to 1991 but actually declined slightly from 1991 to 1994 . This is the only measure that does not show increased black segregation.

The third measure of desegregation used in this study, the exposure index-which calculates the percentage of white students in a school attended by typical black students-shows the level of contact almost as.low as it was before the busing decisions in the early 1970s: $32 \%$, down from its 1980 level of $36.2 \%$ (Table 5). Overall, the level of black segregation in U.S. schools is increasing slowly, continuing an historic reversal first apparent in the 1991 enrollment statistics. 
Table 2

Regular Public School Enrollmenis

by Roce/Ethnicity and Region, 1994-95

\begin{tabular}{|c|c|c|c|c|c|c|}
\hline Region & $\begin{array}{c}\text { Potol } \\
\text { Enrollment }\end{array}$ & \% White & \% Black & \% Lotino & $\begin{array}{l}\text { \% Asion/ } \\
\text { Pacific }\end{array}$ & $\begin{array}{l}\text { \% Indian/ } \\
\text { Aloskan }\end{array}$ \\
\hline South & 13.104 .747 & 57.8 & 27.2 & 13.0 & 1.7 & 0.4 \\
\hline Border & $3,356,431$ & 75.0 & 18.7 & 2.0 & 1.6 & 2.7 \\
\hline Northeast & $7.566,103$ & 70.9 & 14.8 & 10.5 & 3.6 & 0.3 \\
\hline Mictwest & $9,382,999$ & 80.1 & 13.0 & 4.2 & 1.9 & 0.8 \\
\hline West** & 9.478 .267 & 56.6 & 6.3 & 27.4 & 7.6 & 2.1 \\
\hline Alaska & 121,895 & 64.4 & 4.8 & 2.5 & 4.2 & 24.1 \\
\hline Howaii & 183.737 & 23.2 & 2.7 & 4.9 & 68.8 & 0.4 \\
\hline U.S. Total"** & $43,194,179$ & 65.9 & 16.5 & 12.9 & 3.6 & 1.1 \\
\hline
\end{tabular}

Source: 1994-95 NCES Common Core of Dota Public School Universe

- See Appendix B for a list of states included in each region.

- The rocial proportions for ldaho are estimoted from doto collected by the U.S. Department of Education, Office for Civil Rights (OCR) for the 1989-90 school year. The OCR data include $42 \%$ of students in ldoho for 1989-90. The proportions differ by less than $1 \%$ from those reported in the 1990 U.S. Census for all students in ldano.

-.. Aloska, Howaii, and ldaho are included in this table but omitted from subsequent analyses (see Appendix A)

Table 3

Public School Enroliments in Mojorty Non-White Stotes by Roce/Ethnicthy, 1994-95

\begin{tabular}{|c|c|c|c|c|c|c|}
\hline & $\begin{array}{l}\text { Total } \\
\text { Enroliment }\end{array}$ & \% White & \% Black & \% Lotino & $\begin{array}{l}\text { \% Asion/ } \\
\text { Pactific }\end{array}$ & $\begin{array}{l}\text { \% Indian/ } \\
\text { Alaskan }\end{array}$ \\
\hline Californio & $5,168,334$ & 41.4 & 8.5 & 37.8 & 11.4 & 0.8 \\
\hline Howaii & 83.737 & 23.2 & 2.7 & 4.9 & 68.8 & 0.4 \\
\hline Mississippi & 502.985 & 48.0 & 51.0 & 0.3 & 0.5 & 0.1 \\
\hline New Mexico & 320.832 & 39.9 & 2.4 & 46.4 & 1.0 & 10.4 \\
\hline Texas & 3.624 .056 & 47.2 & 14.3 & 36.0 & 2.3 & 0.2 \\
\hline
\end{tabular}

Source: 1994-95 NCES Common Core of Data Public School Universe

Table 4

Percentage of U.S. Black and Laftno Students in Predominantly Minority and $90-100 \%$ Minortly Schools, 1968-94

\begin{tabular}{|l|l|l|l|l|}
\hline \multirow{2}{*}{} & \multicolumn{2}{|c|}{ 50-100\% Minority } & \multicolumn{2}{c|}{ 90-100\% Minority } \\
& Blacks & Latinos & Blacks & Latinos \\
\hline $1968-69$ & 76.6 & 54.8 & 64.3 & 23.1 \\
$1972-73$ & 63.6 & 56.6 & 38.7 & 23.3 \\
$1980-81$ & 62.9 & 68.1 & 33.2 & 28.8 \\
$1986-87$ & 63.3 & 71.5 & 32.5 & 32.2 \\
$1991-92$ & 66.0 & 73.4 & 33.9 & 34.0 \\
$1994-95$ & 67.1 & 74.0 & 33.6 & 34.8 \\
\hline
\end{tabular}

Source: U.S. Department of Education Office for Civil Rights data in Oifield. Public School Desegregation ir the Uniteo States. 1968-1980, tables 1 and 10. 1991-92 and 1994-95 NCES Common Core of Data. 
Toble 5

Porcentoge of White Students in Schools Aftended by

Typical Black or Loftino Students, 1970-94

\begin{tabular}{|l|l|l|}
\hline & BLocks & Lofinos \\
\hline 1970 & 32.0 & 43.8 \\
1980 & 36.2 & 35.5 \\
1980 & 36.0 & 32.9 \\
1991 & 34.4 & 31.2 \\
1994 & 33.9 & 30.6 \\
\hline
\end{tabular}

Source: 1994-95 NCES Common Core of Data Public School Universe

Table 6

Segregation of Block Students by Rogion, $1997-92$ and $1994-95$

\begin{tabular}{|c|c|c|c|}
\hline \multicolumn{4}{|c|}{$1991-92$} \\
\hline & $\begin{array}{l}\% \text { of Elocics in 50-100\% } \\
\text { Minority Schools }\end{array}$ & $\begin{array}{l}\text { \% of Placts in } 90-100 \% \\
\text { Minorthy Schools }\end{array}$ & $\begin{array}{l}\text { \% Whites in School } \\
\text { of Typlcol Hock }\end{array}$ \\
\hline South & 60.8 & 26.6 & 38.3 \\
\hline Border & 59.3 & 33.2 & 37.3 \\
\hline Northeast & 76.2 & 50.1 & 26.1 \\
\hline Midwest & 69.9 & 39.4 & 31.7 \\
\hline West & 69.7 & 26.4 & 34.5 \\
\hline U.S. Tota! & 66.0 & 33.9 & 34.4 \\
\hline \multicolumn{4}{|c|}{$1994-95$} \\
\hline & $\begin{array}{l}\text { \% of Plocks in 50-100\% } \\
\text { Minotity Schoots }\end{array}$ & $\begin{array}{l}\% \text { of Packs in } 90-100 \% \\
\text { Minorthy Schoots }\end{array}$ & $\begin{array}{l}\text { \% Whitos in School } \\
\text { of Typlcol Block }\end{array}$ \\
\hline South & 63.4 & 26.8 & 37.1 \\
\hline Border & 60.8 & 36.7 & 35.9 \\
\hline Northeast & 76.4 & 49.9 & 26.1 \\
\hline Miodwest & 67.1 & 33.6 & 31.1 \\
\hline West & 71.9 & 26.4 & 33.4 \\
\hline U.S. Total & 67.1 & 33.6 & 33.9 \\
\hline
\end{tabular}

SOurce: 1991-92 \& 1994-95 NCES Common Core of Data.

-See Appendix $B$ for a list of states included in each region.

\section{African American Segregation Climbing in the Heartland of the Old Segregation}

The South and the Border regions are leading the nation in the turn back toward segregation for black students. Ever since the civil rights revolution in the 1960 s, the 17 states of these two regions (the 11 states of the Confederacy and the adjoining six states from Oklahoma to Delaware which also maintained state-mandated segregation) have been the center of the least segregated schools for black students. The transforma- tion of this huge region from an area of complete educational apartheid to the least segregated area in the United States was an historic accomplishment. That accomplishment is being lost.

The segregation of black students in the South and Border regions increased between 1991 and 1994 by all three measures used in this study. The percentage of black students attending predominantly minority schools increased more in the South than any other region and the Border region is now reporting a level of intense segregation exceeded only by the Northeast. 
Table 7

Chonge in Block Segregofion in the South, 1967-94

\begin{tabular}{|cc|}
\hline Porcent of Block Students in Mojority White Schools \\
\hline 1954 & .001 \\
1960 & .1 \\
1964 & 2.3 \\
1967 & 13.9 \\
1968 & 23.4 \\
1970 & 33.1 \\
1972 & 36.4 \\
1976 & 37.6 \\
1980 & 37.1 \\
1986 & 42.9 \\
1988 & 43.5 \\
1991 & 39.2 \\
1994 & 36.6 \\
\hline
\end{tabular}

Source: Southern Educction Reporting Senvice in Reed Sarrott. The Ordea of Desegregotion (New York: Horper \& Row. 1966): 362: HEW Press Relecse. May 27. 1968: OCR doto tapes: $1992-92$ and 1994-95 NCES Common Core of Data.

-See Appendtx 8 for a list of states included.

These regions are clearly slipping back toward their far more segregated pasts (Table 6).

In terms of the proportion of black students in desegregated majority white schools, the South increased dramatically from virtually total segregation in 1960, to $13.9 \%$ of blacks in majority white schools in $1967,36.4 \%$ in 1972 , and a high of $43.5 \%$ in 1988 . Since then the number has dropped to $39.2 \%$ in 1991 and $36.6 \%$ in 1994 , losing all the slow progress of the last two decades and heading back toward the levels of segregation before the cities were desegregated (Table 7). On the other measures of segregation the pattern for the region was similar. Its level of intense segregation increased slightly, and the exposure of its black students to white students fell.

The Border region, encompassing the six states from Oklahoma to Delaware that were not part of the Confederacy but had a system of mandated segregation at the time of the Brown decision, experienced a similar rise in segregation from 1991 to 1994-95. The region went from having $59 \%$ of its black students in predominantly minority schools to $61 \%$ in three years. The percentage in intensely segregated schools climbed from $33.2 \%$ to $36.7 \%$, and exposure of black students to whites also declined (Table 6).

The most segregated regions for the past generation, the Northeast and the Midwest, continued to lead the list in 1994, although the Midwest was surpassed by the West in the percentage of students in predominantly minority schools and by the Border region in intense segregation. Segregation in the Northeast remained about the same, continuing to have about half of its black students in schools that are $90-100 \%$ non-white, far surpassing other regions in the level of intense segregation (Table 6).

\section{TRENDS FOR LATINO STUDENTS}

Latino segregation has become substantially more severe than African American segregation by each of the measures used in this study. In the Northeast, the West, and the South, more than three-fourths of all Latino students are in predominantly non-white schools, a level of isolation found for African American students only in the Northeast (Table 8). We have been reporting these trends continuously for two decades. They are clearly related to inferior education for Latino students. ${ }^{13}$ Although data are limited, the surveys that have been done tend to show considerable interest in desegregated education among Latinos and substantial support for busing if there is no other way to achieve integration.14

All three measures of segregation reported in Tables 4 and 5 show a continuing gradual increase in segregation for Latino students nationally. The most significant change comes in the proportion of students in intensely segregated schools, which rose to $34.8 \%$ in 1994 . In 1968 , only $23.1 \%$ of Latino students were in these isolated and highly impoverished schools, compared to $64.3 \%$ of black students (Table 4). Now the percentage of Latino students in such schools is up by almost half and is slightly higher than the level of intense segregation for black students.

\section{Regional Segregation for Latinos}

Since the statistics on Latino segregation were first collected, segregation has always been most intense in the Northeast, where most Latinos are from Puerto Rico and other Caribbean islands. By 1994, the isolation of Latinos was still intense in the Northeast and was also high in the South and West. In all three regions, over $75 \%$ of Latinos were in schools with majorities of black or Latino students (Table 8). The West, deeply shaped by the migration of Mexican Americans and Mexicans, now isolates Latinos at levels exceeding the national figures for blacks. ${ }^{15}$

Since Latino students are experiencing far higher dropout rates than African Americans, and the majority of Latino students live in two states where the education officials have adopted policies ending affirmative action for college admissions, the increasing concentration of students in low achieving, high-poverty schools, where few children prepare competitively for college, raises extremely important issues. If the growing community of Latino students is increasingly isolated in inferior schools, and standards are raised without the schools having the means to meet them, there could be a vicious cycle of declining opportunity. 
Toble 8

Lotino Segregation by Region," 1994-95

\begin{tabular}{|l|c|c|c|}
\hline & $\begin{array}{c}\text { \% in 50-100\% } \\
\text { Minority Schools }\end{array}$ & $\begin{array}{c}\text { \% in 90-100\% } \\
\text { Minotity Schools }\end{array}$ & $\begin{array}{c}\text { \% Whites in School } \\
\text { of Typicol Lotino }\end{array}$ \\
\hline South & 75.6 & 38.0 & 28.6 \\
Border & 40.8 & 12.3 & 53.2 \\
Northeast & 77.6 & 45.1 & 26.7 \\
Midwest & 53.1 & 21.8 & 49.6 \\
West & 75.9 & 32.1 & 30.3 \\
& & 34.8 & 30.6 \\
\hline
\end{tabular}

Source: 1994-95 NCES Common Core of Data: Hanard Project on Desegregation.

"See Appendix 8 for a list of states in each region.

\section{RACE AND POVERTY}

The relationship between segregation by race and segregation by poverty in public schools across the nation is exceptionally strong. The correlation between the percentage of black and Latino enrollments and the percentage of students receiving free lunches is an extremely high .72 . This means that racially segregated schools are very likely to be segregated by poverty as well.

There is strong and consistent evidence from national and state data from across the United States as well as from other nations that high poverty schools usually have much lower levels of educational performance on virtually all outcomes. This is not all caused by the school; family background is a more powerful influence. Schools with concentrations of low income children have less prepared children. Even better prepared children can be harmed academically if they are placed in a school with few other prepared students and, in some cases, in a social setting where academic achievement is not supported.

School achievement scores in many states and in the nation show a very strong relation between poverty concentrations and low achievement. ${ }^{16}$ This is because high poverty schools are unequal in many ways that affect educational outcomes. The students' parents are far less educated-a very powerful influence-and the child is much more likely to be living in a single parent home that is struggling with multiple problems. Children are much more likely to have serious developmental and untreated health problems. Children move much more often, often in the middle of a school year, losing continuity and denying schools sufficient time to make an impact on their learning.

High poverty schools have to devote far more time and resources to family and health crises, security, children who come to school not speaking standard English, seriously disturbed children, children with no educational materials in their homes, and many children with very weak educational preparation. These schools tend to draw less qualified teachers and to hold them for shorter periods of time. They tend to have to invest much more heavily in remediation and much less adequately in advanced and gifted classes and demanding materials. The levels of competition and peer group support for educational achievement are much lower in high poverty schools. Such schools are viewed much more negatively in the community and by the schools and colleges at the next level of education as well as by potential employers. In those states that have implemented high stakes testing, which denies graduation or flunks students, the high poverty schools tend to have by far the highest rates of sanctions. 17

None of this means that the relationship between poverty and educational achievement is inexorable, or that there are not exceptions. Many districts have one or a handful of high poverty schools that perform well above the normal pattern. Students from the same family background may perform at very different levels of achievement, and there are some highly successful students and teachers in virtually every school. The overall relationships, however, are very powerful. Students attending high poverty schools face a much lower level of competition regardless of their own interests and abilities.

This problem is intimately related to racial segregation. The bottom row of Table 9 shows that $60.7 \%$ $(50.3+10.4)$ of the schools in the United States have less than one-fifth black and Latino students, while $9.2 \%$ $(2.7+6.5)$ have $80-100 \%$ black and Latino students. At the extremes, only $5.4 \%$ of the schools with $0-10 \%$ black and Latino students have more than half low income students; $70.5 \%(33.1+37.4)$ of them have less than onefourth poor students. Among schools that are 90-100\% black and/or Latino, on the other hand, almost ninetenths $(87.7 \%)$ are predominantly poor, and only about $3 \%(1.2+1.6)$ have less than one-fourth poor children. A student in a segregated minority school is 16.3 times 
Toble 9

Relationship Betwoen Segregatton by Race and by Poverty, 1994-95

\begin{tabular}{|c|c|c|c|c|c|c|c|c|c|c|}
\hline \multicolumn{11}{|c|}{ Percent Black and Latino Students in Schools } \\
\hline $\begin{array}{l}\text { \% Poor } \\
\text { in Schools }\end{array}$ & $0-10 \%$ & $10-20 \%$ & $20-30 \%$ & $30-60 \%$ & $40-50 \%$ & $50-60 \%$ & $60-70 \%$ & $70-80 \%$ & $80-90 \%$ & $90-100 \%$ \\
\hline $0-10 \%$ & 33.1 & 21.1 & 7.2 & 3.2 & 2.2 & 2.0 & 1.3 & 1.4 & 1.2 & 1.2 \\
\hline $10-25 \%$ & 37.4 & 39.4 & 34.1 & 22.1 & 12.4 & 7.9 & 3.8 & 3.1 & 2.9 & 1.6 \\
\hline $25-50 \%$ & 24.1 & 31.8 & 45.9 & 52.5 & 49.6 & 40.3 & 27.5 & 18.0 & 14.2 & 9.5 \\
\hline $50-100 \%$ & 5.4 & 7.2 & 12.8 & 22.2 & 35.8 & 49.7 & 67.4 & 77.5 & 81.7 & 87.7 \\
\hline Total & 100 & 100 & 100 & 100 & 100 & 100 & 100 & 100 & 100 & 100 \\
\hline $\begin{array}{l}\text { \% of U.S. } \\
\text { Schools }\end{array}$ & 50.3 & 10.4 & 7.8 & 6.3 & 5.4 & 4.4 & 3.4 & 2.8 & 2.7 & 6.5 \\
\hline
\end{tabular}

Note: The correlation between the percentoge of block and Latno enrottments and the percentoge of free tunch eligible is .72. Note: The actual percentage cotegories are 0-10. 10.1-20, 20.1-30, 30.1-40 etc.

Sounce: 1994-95 NCES Common Core of Data: Hanard Project on Desegregation

more likely to be in a concentrated poverty school than a student in a segregated white school. ${ }^{18}$

\section{WHIERE IS SEGREGATION CONCENTRATED? THE LONG-TERM EFIFECTS OF THE SUPREME COURT'S DECISION AGAINST SUBUIRBAN DESEGREGATION}

Blacks living in rural areas and in small and mediumsized towns or the suburbs of small metropolitan areas are far more likely to experience substantial school desegregation than those living in the nation's large cities; they attend schools with an average of about $50 \%$ white students (Table 10). In contrast, blacks in large cities attend schools that have an average of only $17 \%$ white students and those in smaller cities attend schools with an average of $38 \%$ white students. Black students in the suburbs of large cities attend schools with an average of $41 \%$ white students (Table 10). Considering the small proportion of minority students in many suburban rings, this level of segregation is a poor omen for the future of suburbs that will become more diverse.

The nation's non-white population is extremely concentrated in metropolitan areas. Outside the South, this concentration tends to be in the largest metropolitan areas with the largest ghettos and barrios. Many of the small cities and towns in Illinois and Michigan, for example, have few African American students, and the vast majority of the nation's white students live in suburbs divided into scores of separate school districts, all laid over extremely segregated metropolitan housing markets. This means that the central city school districts become extremely isolated by race and poverty and are critical only for non-white students. Since the minority communities are constantly expanding along their boundaries, and virtually all-white developments are continuously being constructed on the outer periphery of suburbia, the central cities have a continual increase in their proportion of black and Latino students.

The suburbs are now the dominant element of our society and our politics. As the nation's population changes dramatically in the coming decades, suburbs are destined to become much more diverse. What kind of access black and Latino children will have to mainstream suburban society will be affected by the racial characteristics of suburban schools. It raises serious concerns to realize that by 1994, blacks were in schools that averaged only $41 \%$ white students, and Latinos were in schools that averaged just $36 \%$ white students, in the suburbs of the largest cities. Whites in those suburban rings were in schools with an average of only $14 \%(6.8 \%$ $+7.1 \%$ ) combined black and Latino enrollments. Latino students, but not blacks, were almost as segregated in the suburbs of smaller metropolitan areas (Table 10). If these patterns intensify as the suburban African American and Latino population grows, we may be facing problems that are as serious as those that led to desegregation conflicts in many cities.

It would be profoundly ironic if the Supreme Court decision that meant to protect suburban boundary lines (Milliken $v$. Bradley) ended up making it impossible for suburban communities in the path of racial change to avoid rapid resegregation. Individual suburban school districts are often so small that they can go through racial change much more rapidly and irreversibly than a huge city. A suburb will often have only the enrollment of a single high school attendance area in a city and has little hope of stabilizing its enrollment, once a major racial change begins, without drawing on students from a broader geographic area. This means that in areas with many fragmented school districts, not only the city but also substantial portions of suburban rings may face high levels of segregation. 
Toble 10

Exposure of Blocks, Lofinos, and Whites to Siudenis of Other Groups, by Size of Communtty, 1994-95

\begin{tabular}{|c|c|c|c|c|}
\hline \multirow[t]{2}{*}{ Community Type } & \multicolumn{2}{|c|}{$\begin{array}{l}\text { \% Whito in } \\
\text { School of Typical } \\
\text { Black of Lotino }\end{array}$} & \multicolumn{2}{|c|}{$\begin{array}{l}\text { \% Ainorlty in } \\
\text { School of Typicai } \\
\text { Whitie }\end{array}$} \\
\hline & Block & Lotinos & Black & Lollinos \\
\hline \multicolumn{5}{|l|}{ Large Metro } \\
\hline City & 16.6 & 17.2 & 18.6 & 15.8 \\
\hline Suburbs & 41.2 & 36.1 & 6.8 & 7.1 \\
\hline \multicolumn{5}{|l|}{ Small Metro } \\
\hline City & 38.3 & 36.2 & 13.7 & 7.8 \\
\hline Suburbs & 57.8 & 37.3 & 7.1 & 3.7 \\
\hline \multicolumn{5}{|l|}{ Towns } \\
\hline $25.000+$ & 50.2 & 45.4 & 8.8 & 5.2 \\
\hline Small & 47.4 & 45.1 & 7.7 & 3.8 \\
\hline Rural & 47.3 & 54.0 & 4.6 & 2.3 \\
\hline
\end{tabular}

Note: Large metro areas have cities with population of 250.000 of greater; small metro areas have cities with populotions of less than 250.000 . SOurce: 1994-95 NCES Common Core of Data: Harvard Project on Desegregation

Table 11

Enrollment of Ten Largest Contral Chy School Districts and Porcent of Nallonal Enrollment by Raco/Emnicity, 1994-95

\begin{tabular}{|c|c|c|c|c|c|}
\hline Cony & Enrollment & \% White & \% Block & \% Laitino & \% Ation \\
\hline Now York & 953.535 & 17.6 & 36.0 & 36.5 & 9.5 \\
\hline Los Angeles & 613,192 & 11.4 & 14.0 & 67.2 & 7.2 \\
\hline Chicogo & 402,136 & 11.3 & 54.7 & 30.6 & 3.2 \\
\hline Dade (Miami) & 314,881 & 15.1 & 33.8 & 49.7 & 1.3 \\
\hline Philadelphia & 202.387 & 21.1 & 63.1 & 10.9 & 4.7 \\
\hline Houston & 197.722 & 11.7 & 35.2 & 50.3 & 2.7 \\
\hline Detroit & 164.258 & 6.3 & 89.7 & 2.8 & 0.9 \\
\hline Dallas & 142,630 & 12.8 & 43.5 & 41.6 & 1.7 \\
\hline San Diego & 125.389 & 30.7 & 16.7 & 32.3 & 19.7 \\
\hline Memphis & 109.611 & 16.8 & 81.8 & 0.4 & 1.1 \\
\hline$\%$ of U.S. Tota: & $7.5 \%$ & $1.7 \%$ & $17.8 \%$ & $22.7 \%$ & $12.5 \%$ \\
\hline
\end{tabular}

Source: 1994-95 NCES Common Core of Data and computations by Horvard Profect on School Desegregation

Since non-white suburbanization began in earnest in the 1970s, the cities also have been losing many of their minority middle-class families, leaving the cities with an escalating concentration of poverty. Table 11 shows the enrollment of the nation's ten largest city school districts for 1994-95. These districts contain 18\% black students, $23 \%$ Latino students, $13 \%$ Asian students, but only $2 \%$ of the whites. About a fifth of black and Latino students depend on districts that do not matter to $98 \%$ of white families. Most of these systems have faced recurrent fiscal and political crises for years and have low levels of educational achievement. Desegregation has become virtually impossible in some of these systems since the
Milliken decision. The trends of metropolitan racial change since World War II suggest that segregation will become worse in the future.

\section{Consequences of Smaller Districts}

Different parts of the country traditionally have very different patterns of organizing school districts, depending in part on local traditions and, in part, on whether or not the districts were organized back when the horse and buggy meant that units of local government had to be very small. In much of the South, counties have tradition- 
ally been more important and municipalities less important. In New' England the towns existed long before they became part of suburban rings in large metropolitan areas. School districts in the South were often countywide; in the Northeast and the older parts of the Midwest, they were often defined by the structure of local town government set generations in the past. When the Supreme Court decided in 1974 to make it very difficult to desegregate across school district boundary lines, it virtually guaranteed that the regions with large districts would be far less segregated than those with small districts.

The nation's largest school districts are in Maryland, Florida, Louisiana, North Carolina, West Virginia, and Delaware, all states in the Southern and Border regions. Illinois, New York, New Jersey, and Michigan, consistently the most segregated states for black students, have much smaller districts as do Texas and California, where most Latino students are concentrated. There has been no absolute relationship between district size and segregation, of course, because of the widely varying proportions of black and Latino students within various states and because of different types of desegregation plans in place in different areas. Nonetheless, the most segregated states tend to be fragmented into a great many small districts, and the most integrated states tend to have very different patterns, although there are significant exceptions to this pattern. The Maryland and Louisiana statistics show, for example, that it is possible to have very large districts with very high levels of segregation, while the Indiana and Ohio statistics show that small districts in states with multiple desegregation orders and a small black population are compatible with a lower level of intense segregation (Table 12).

No state with small districts and a substantial African American population has come anywhere near the level of desegregation achieved in the most successful states with large systems. North Carolina and Tennessee, which already have relatively large districts, have seen city and suburban districts consolidated in recent years to create more countywide systems.

\section{CHANGING PATTERNS OF SEGREGATION AT THE STATE LEVEL}

The four states with the highest levels of segregation for black students have been unchanged since 1980. In Illinois, Michigan, and New York, about a fifth of the students in schools with a black student majority are white; in New Jersey, about a fourth are white (Table 13). These are averages - each of these states has many completely segregated schools. Since 1980, Michigan and New Jersey have actually increased their already very high proportion of black students in intensely segregated schools.

Other northern states that rank very high in the segregation of black students are Pennsylvania and Connecticut. In Pennsylvania, Philadelphia is the center of
Table 12

Median Siz of School Districts and Sogregation of Black Students, Selected Stotes, 1994-95

\begin{tabular}{|l|c|c|}
\hline & $\begin{array}{c}\text { Miedian } \\
\text { Distidel Size }\end{array}$ & $\begin{array}{c}\text { \% in } 90-100 \% \\
\text { Milinority Schools }\end{array}$ \\
\hline Maryland & 13.955 & 46.0 \\
Florida & 12.700 & 26.1 \\
Louisiana & 6.343 & 37.6 \\
North Carolina & 5.704 & 7.1 \\
Delaware & 3.797 & 0.9 \\
South Carolina & 3.723 & 17.0 \\
Virginia & 3.509 & 12.7 \\
Tennessee & 3.280 & 38.0 \\
Alabama & 3.255 & 38.2 \\
Connecticut & 1.920 & 35.1 \\
Indiano & 1.920 & 23.3 \\
Ohio & 1.831 & 18.3 \\
Michigan & 1.642 & 59.6 \\
California & 1.509 & 34.1 \\
New York & 1.475 & 57.1 \\
Now Jersey & 1.063 & 53.7 \\
Wisconsin & 981 & 20.5 \\
Illinois & 859 & 61.9 \\
Texas & 841 & 31.9 \\
\hline
\end{tabular}

Source: 1994-95 NCES Common Core of Dato: Honard Project on School Desegregation.

segregation. Connecticut has a relatively small black enrollment $(12.9 \%)$, but its share of black students in intensely segregated schools (35.1\%) is almost the same as Mississippi, which has $51 \%$ black students. Connecticut is getting worse faster, partly because of the extreme fragmentation of its relatively compact metropolitan areas. In Connecticut, the state supreme court has ruled that the system of segregated districts in metropolitan Hartford violates the state constitution and has ordered the legislature to design a remedy.

The most dramatic change is the rapid increase of segregation below the Mason-Dixon line. After a long period following the civil rights revolution in which none of the 17 states that had mandated segregation by state law was among the leaders in segregation, the pattern is changing in the $1990 \mathrm{~s}$. Three of those states are now among the ten most segregated for black students on all three measures calculated for this study: Maryland, Mississippi, and Louisiana. Alabama is close behind. Maryland and Tennessee, together with Michigan, are leaders in the growth of intense segregation of black students since 1980. Maryland has seen a rapid spread of suburban segregation in Prince George, Montgomery, and Baltimore counties, major suburbs of Washington, D.C., and Baltimore. Mississippi has the nation's highest proportion of black students. 
Table 13

Most Segregated States ${ }^{\circ}$ for Black Students on Three Meosures of Segregotion, 1994-95

\begin{tabular}{|c|c|c|c|c|c|}
\hline \multicolumn{2}{|c|}{$\begin{array}{l}\% \text { in Majority } \\
\text { White Schools }\end{array}$} & \multicolumn{2}{|c|}{$\begin{array}{l}\% \text { in } 90-100 \% \\
\text { Minority Schools }\end{array}$} & \multicolumn{2}{|c|}{$\begin{array}{l}\text { \% Whites in Schoo! } \\
\text { of Typical Black }\end{array}$} \\
\hline New York & 15.1 & Illinois & 61.9 & Illinois & 20.0 \\
\hline California & 175 & Michigan & 59.6 & New York & 20.1 \\
\hline Michigan & 18.8 & New York & 57.1 & Michigan & 20.8 \\
\hline Illinols & 20.2 & New Jersey & 53.7 & New Jersey & 257 \\
\hline Mississippi & 23.3 & Pennsylvanio & 47.0 & California & 26.0 \\
\hline Maryland & 25.9 & Maryland & 46.0 & Maryland & 27.3 \\
\hline New Jersey & 26.6 & Alabama & 38.2 & Mississipp: & 28.5 \\
\hline Louisiana & 28.8 & Tennessee & 38.0 & Louisiana & 30.4 \\
\hline Wisconsin & 29.2 & Louisiana & 37.6 & Pennsylvanio & 30.4 \\
\hline Pennsylvania & 30.4 & Mississippi & 36.9 & Alabamo & 32.9 \\
\hline Georgia & 30.8 & Connecticut & 35.1 & Texas & 33.0 \\
\hline Texas & $3 ! \cdot 3$ & California & 34.1 & Georgia & 34.1 \\
\hline Onio & 32.8 & Texas & 31.9 & Connecticut & 34.7 \\
\hline Alabama & 34.1 & Georgio & 29.9 & Tennessee & 35.1 \\
\hline Connecticut & 34.3 & Missouri & 26.3 & Wisconsin & 35.4 \\
\hline
\end{tabular}

Source: 1994-95 NCES Common Core of Dota: Harvard Project on School Desegregation.

-See Appendix C for tables including all states and changes in eoch meosure from 1989-90 to 1994-95.

Table 14

Changing Patterns of Black Segregotion by State, 1970-94 Changes in the Percentage of White Students in Schoots Aitended by Iypical Black Students

\begin{tabular}{|c|c|c|c|c|c|}
\hline & 1970 & 1980 & 1994 & $\begin{array}{l}\text { Chonge } \\
1970-80\end{array}$ & $\begin{array}{l}\text { Change } \\
1990-94\end{array}$ \\
\hline Alabama & 32.7 & 39.7 & 32.9 & 7.0 & -6.8 \\
\hline Arkansas & 42.5 & 46.5 & 42.3 & 4.0 & -4.2 \\
\hline Collifornia & 25.6 & 27.7 & 26.0 & 2.1 & -1.7 \\
\hline Connecticut & 44.1 & 40.3 & 34.7 & -3.8 & -5.6 \\
\hline Deloware & 46.5 & 68.5 & 63.0 & 22.0 & -5.5 \\
\hline Florida & 43.2 & 50.6 & 40.1 & 7.4 & -10.5 \\
\hline Georgia & 35.1 & 38.3 & 34.1 & 3.2 & -4.2 \\
\hline Illinois & 14.6 & 19.0 & 20.0 & 4.4 & 1.0 \\
\hline Indiana & 31.7 & 38.7 & 47.2 & 7.0 & 8.5 \\
\hline Kentucky & 49.4 & 74.3 & 70.5 & 24.9 & -3.8 \\
\hline Louisiana & 30.8 & 32.8 & 30.4 & 2.0 & -2.4 \\
\hline Maryland & 30.3 & 35.4 & 27.3 & 5.1 & -8.1 \\
\hline Massachusetts & 47.5 & 50.4 & 43.2 & 2.9 & -7.2 \\
\hline Michigan & 21.9 & 22.5 & 20.8 & 0.6 & -1.7 \\
\hline Mississippi & 29.6 & 29.2 & 28.5 & -0.4 & -0.7 \\
\hline Missouri & 21.4 & 34.1 & 39.6 & 12.7 & 5.5 \\
\hline New Jersey & 32.4 & 26.4 & 25.7 & -6.0 & -0.7 \\
\hline New York & 29.2 & 23.0 & 20.1 & -6.2 & -2.9 \\
\hline North Carolina & 49.0 & 54.0 & 49.2 & 5.0 & -4.8 \\
\hline Ohio & 28.4 & 43.2 & 38.8 & 14.8 & -4.4 \\
\hline Oklahoma & 42.1 & 57.6 & 47.4 & 15.5 & -10.2 \\
\hline Pennsylvania & 27.8 & 29.3 & 30.4 & 1.5 & 1.1 \\
\hline Rhode Island & NA & 65.8 & 47.2 & NA & -18.6 \\
\hline South Carolina & 41.2 & 42.7 & 40.9 & 1.5 & -1.8 \\
\hline Tennessee & 29.2 & 38.0 & $35: 1$ & 8.8 & -2.9 \\
\hline Texas & 30.7 & 35.2 & 33.0 & 45 & -2.2 \\
\hline Virginio & 41.5 & 47.4 & 455 & 5.9 & -1.9 \\
\hline Wisconsin & 25.7 & 44.5 & 35.4 & 18.8 & -9.1 \\
\hline
\end{tabular}




\section{Long-Term Trends in Black Segregation by State}

The largest increases in the segregation of black students during the last 14 years came in Oklahoma, Florida, Rhode Island, and Wisconsin (Table 14). Oklahoma City was the first city to be permitted to return to segregated neighborhood schools under a Supreme Court decision. In Florida the major cause was a great expansion of the state's urban communities without the development of updated desegregation plans as ghettos expanded and vast new areas of white suburbia were built. In Wisconsin, metropolitan Milwaukee has had extreme residential segregation and, with the continuing loss of whites from the city, the desegregation plan has had a more limited effect. After the failure of Milwaukee's lawsuit to force city-suburban desegregation, many black students were left in segregated inner city schools. Some of them, led by an African-American state legislator, supported the creation of private schools whose students received vouchers from the state government for tuition costs. (An intense scholarly debate has been waged over the past several years on the efficacy of the voucher program.)

During the 1970s, there were substantial increases in desegregation for blacks in a number of states, with huge gains from the city-suburban desegregation orders in Kentucky and Delaware and very substantial gains from the urban desegregation plans, limited to the cities, in Wisconsin and Ohio. Since 1980, the only states with a greater than $5 \%$ black student population to experience a significant increase in desegregation, however, were Missouri and Indiana, two of the very few states to obtain court orders for desegregation across city-suburban boundary lines. Almost all of the other states with significant black enrollments were moving toward shrinking contact between black and white students.

\section{Segregation in States with Few Blacks}

Among the states where fewer than a twentieth of the students are African American, three-New Mexico, Minnesota, and Arizona-have the highest levels of segregation. New Mexico, which has almost half Latino and Indian students, is a special case since the state has relatively few white students and a small black enrollment. Much more perplexing are Minnesota and Arizona, which have just over $4 \%$ black students, but each reports more than $53 \%$ of those students attend majority non-white schools (Table 15). Arizona also reports that an eighth of its African American students are in intensely segregated schools. One major problem is the division of students living within the Phoenix city boundaries into many separate school systems. In Minnesota, the Minneapolis school board and mayor are now pressing for an end of the city's desegregation plan, which would intensify the segregation. Oregon and Washington also have very small fractions of black students and considerable segregation.

Table 15

Segregotion of Black Students in Stotes wth Loss Than Five Percent \&ack Public School Enrollment, 1994-95

\begin{tabular}{|l|c|c|c|}
\hline & \% slock & $\begin{array}{c}\text { \% in 50-100\% } \\
\text { Minority Schoots }\end{array}$ & $\begin{array}{c}\text { \% in } 90-100 \% \\
\text { Minority Schools }\end{array}$ \\
\hline Arizona & 4.2 & 53.1 & 12.3 \\
lowa & 3.1 & 8.5 & 0.0 \\
Moine & 0.7 & 0.0 & 0.0 \\
Minnesota & 4.1 & 53.9 & 0.4 \\
Montana & 0.5 & 5.8 & 1.6 \\
New Hampshire & 0.8 & 0.0 & 0.0 \\
New Mexico & 2.4 & 55.0 & 6.4 \\
North Dakoto & 0.8 & 0.3 & 0.1 \\
Oregon & 2.5 & 32.5 & 0.0 \\
South Dakota & 0.8 & 1.0 & 0.0 \\
Utah & 0.6 & 8.2 & 0.1 \\
Vermont & 0.7 & 0.0 & 0.0 \\
Washington & 4.6 & 29.5 & 0.8 \\
West Virginio & 3.9 & 9.7 & 0.0 \\
Wyoming & 1.0 & 4.4 & 0.0 \\
\hline
\end{tabular}

Source: 1994-95 NCES Common Core of Dato Public Schoo. Un verse 


\section{State Segregation Levels for} Latinos

One of the reasons why the explosion of Latino enrollment has received so little attention, and the issue of Latino segregation has been largely ignored, is that although the effects are considerable in a small number of states, including the nation's largest, the vast majority of Latinos live in just eight states. The growth of Latino enrollment in most of these states has been massive (Table 16). In the last quarter century, six of the eight high enrollment Latino states have had an increased Latino enrollment of at least $130 \%$ in a period of little overall growth in enrollments. These are enormous changes, particularly those affecting three of the nation's largest states.

New York has been the national leader in segregation of Latino students since 1980, and it remains in that position (Tables 17 and 18). New York is maintaining a long-established pattern of intense segregation, both in residence and schools, for Latinos. Puerto Ricans, who are heavily concentrated in New York, have been segregated more than other major Latino groups.

The biggest increases in segregation for Latinos came in California, Nevada, and Connecticut. Other states are moving toward New York's intense level of segregation.

Of the states with a significant Latino enrollment, only Colorado, Nevada, and Wyoming continued to have their Latino students in schools that averaged over $50 \%$ white in 1994 , and only Wyoming has experienced increasing desegregation (Table 17). Colorado had a gain in desegregation for Latinos in the 1970s thanks to the Supreme Court decision ordering desegregation for Mexican Americans as well as blacks in Denver. ${ }^{19}$ After the data in this report were collected, Denver received permission from the federal court to resegregate its schools, which was done in the fall of 1996. When the next data is collected, Colorado will probably look more like the rest of the Southwest.

The nation's two largest states, California and Texas, both show substantial increases in segregation of Latino students and, in each, Latino students are attending schools with average enrollments that are only $25 \%$ white (Tables 17 and 18). These two states are home to $59 \%$ of the nation's Latino students and rank second and third in the national segregation measures. New Jersey ranks fourth in Latino segregation, thanks to the residential segregation of Latinos and the fragmentation of the state's urban communities into many independent school districts.

\section{Segregation of Whittes at the State Level}

In a nation where whites are destined to become one of several minorities in the schools if the existing trends continue, it is important not only to consider the isolation of non-white students from whites but also the isolation of whites from the growing parts of the population.

Except in the historic de jure states for blacks and the states taken from Mexico in the war in the 1840s, most white students have not yet experienced substantial desegregation. Although they are growing up in a society where the U.S. Census Bureau predicts that more than half of schoolage children will be non-white in a third of a century, many are being educated in overwhelmingly white schools with little contact with black or Latino

Table 16

Growth of Lofino Enrosiments, 1970-94

Stofies wth More Than 100,000 Lofino Students in 1994

\begin{tabular}{|c|c|c|c|c|}
\hline & \multirow[b]{2}{*}{1970} & \multirow[b]{2}{*}{1994} & \multicolumn{2}{|c|}{ Chonge $1970-94$} \\
\hline & & & Number & Percent \\
\hline California & 708.900 & 1.953 .343 & $1,246,443$ & 176.3 \\
\hline Texas & 565.900 & $1,304,269$ & 738.369 & 130.5 \\
\hline New York & 316,600 & 440,043 & 123,443 & 39.0 \\
\hline Florida & 65,700 & 301.206 & 235,506 & 3585 \\
\hline Illinois & 78,100 & 218.568 & 140,468 & 179.9 \\
\hline Arizona & 85.500 & 203,097 & 117.597 & 137.5 \\
\hline New Mexico & 109,300 & 148.772 & 39.472 & 36.1 \\
\hline New Jersey & 59,100 & 148,345 & 89.245 & 151.0 \\
\hline
\end{tabular}

Source: DBS Corp., 1982: 1987: 1994-95 NCES Common Core of Dato Pablic Schoo Universe. 
Many states have adopted policies to publicize achievement results by district and by school. They repeatedly publish lists that show urban minority schools with very high levels of concentrated poverty at the bottom in academic achievement without ever discussing the relationship between segregated education and low achievement. 22 If standards are to be raised for students, states must be concerned about the structural fairness of their system for minority students.

\section{CONCLUSION}

In American race relations, the bridge from the twentieth century may be leading back into the nineteenth century. We may be deciding to bet the future of the country once more on "separate but equal." There is no evidence that separate but equal today works any more than it did a century ago.

The debate that has been stimulated by recent Supreme Court decisions is a debate about how and when to end desegregation plans. The most basic need now is for a serious national examination of the cost of resegregation and the alternative solutions to problems with existing desegregation plans. Very few Americans prefer segregation, and most believe that desegregation has had considerable value, but most whites are still opposed to plans that involve mandatory transportation of students. During the last 15 years, plans have been evolving to include more educational reforms and choice mechanisms to try to achieve desegregation and educational gains simultaneously. A stronger fair housing law, a number of settlements of housing segregation cases, and federal initiatives to change the operation of subsidized housing -as well as the very rapid creation of brand new communities in the sunbelt-all offer opportunities to try to change the pattern of segregated housing that underlies school segregation. Policies that would help move the country toward a less polarized society include:

1. Resumption of serious enforcement of desegregation by the Justice Department and serious investigation of the degree to which districts have complied with all Supreme Court requirements by the Department of Education. Such requirements could be appropriately specified in a federal regulation.

2. Creation of a new federal education program to train students, teachers, and administrators in human relations, conflict resolution, and multi-ethnic education techniques and to help districts devise appropriate plans and curricula for successful multiracial schools.

3. Serious federal research on multiracial schools and the comparative success of segregated and desegregated schools.

4. A major campaign to increase non-white teachers and administrators through a combination of employment discrimination enforcement and resources for recruitment and education of potential teachers.
5. Incorporation of successful desegregation into the national educational goals.

6. Federal and state efforts to expand the use of integrated two-way bilingual programs from the demonstration stage to a major technique for improving second language acquisition for both English speakers and other language speakers and for building successful ethnic relationships.

7. Additional Title IV resources to expand state education department staffs working on desegregation and racial equity in the schools.

8. Federal, state, and local plans to coordinate housing policy with school desegregation policy:

9. Examination of choice and charter school plans to assure that they are not increasing segregation and to reinforce their potential contribution to desegregation.

10. Examination of high stakes state testing programs to ensure that they are not punishing the minority students who must attend inferior segregated schools under existing state and local policies.

\section{APPENDIX A: DATA SOURCES}

Unless otherwise noted, the data source for all tables on 1994 statistics is the 1994-95 NCES Common Core of Data School Universe. Schools included in the analyses are all Type 1 (regular) schools in Types 1-4 agencies. Alaska, Hawaii, and U.S. possessions are excluded, except when noted. Idaho is excluded from most tables because school enrollments by race were not reported by that state to NCES. The data analyzed are from 78,605 schools in 14,283 districts in 47 states and Washington, DC. The following states did not report the number of free lunch eligible students: Alabama, Arizona, lllinois, Kentucky, Massachusetts, New Mexico, Pennsylvania, and Washington and, therefore, could not be included in the national calculations of the relationship between segregation by race and poverty in the schools.

\section{APPENDIX B: DEFINITION OF REGIONS}

South: Alabama, Arkansas, Florida, Georgia, Louisiana, Mississippi, North Carolina, South Carolina, Tennessee, Texas, and Virginia.

Border: Delaware, Kentucky, Maryland, Missouri, Oklahoma, and West Virginia.

Northeast: Connecticut, Maine, Massachusetts, New Hampshire, New' Jersey, New York, Pennsylvania, Rhode Island, and Vermont.

Midwest: Illinois, Indiana, Iowa, Kansas, Michigan, Minnesota, Nebraska, North Dakota, Ohio, South Dakota, and Wisconsin.

West: Arizona, California, Colorado, Montana, Nevada, New Mexico, Oregon, Utah, Washington, and Wyoming.

Note: Alaska and Hawaii are excluded from most parts of this study because of their unique ethnic compositions and isolation from the regions studied here. Analyses of these states would require close attention to Asian and American Indian populations and could be carried out from the same dataset. 


\section{APPENDIX C}

Table 1

Stale Rankings in the Segregotion of Black Students by Three Measures, 1994-95 School Year

\begin{tabular}{|c|c|c|c|c|c|c|}
\hline Rank & $\begin{array}{l}\% \text { in Majority } \\
\text { White Schools }\end{array}$ & & $\begin{array}{l}\% \text { in } 90-100 \% \\
\text { Minority Schools }\end{array}$ & & $\begin{array}{c}\text { \% Whites in School } \\
\text { of Iypical Block }\end{array}$ & \\
\hline 1 & Dist. of Columbia & 0.4 & Dist. of Columbia & 96.1 & Dist. of Columbia & 1.4 \\
\hline 2 & New York & 15.1 & Illinois & 61.9 & Illinois & 20.0 \\
\hline 3 & California & 17.5 & Michigan & 59.6 & New York & 20.1 \\
\hline 4 & Michigan & 18.8 & New York & 57.1 & Michigan & 20.8 \\
\hline 5 & Illinois & 20.2 & New Jersey & 53.7 & New Jersey & 25.7 \\
\hline 6 & Mississippi & 23.3 & Pennsylvania & 47.0 & Colifornia & 26.0 \\
\hline 7 & Marylano & 25.9 & Maryland & 46.0 & Maryiand & 27.3 \\
\hline 8 & New Jersey & 26.6 & Alabama & 38.2 & Mississipp: & 28.5 \\
\hline 9 & Louisiana & 28.8 & Tennessee & 38.0 & Louisiana & 30.4 \\
\hline 10 & Wisconsin & 29.2 & Lovisiona & 37.6 & Pennsylvanic & 30.4 \\
\hline 11 & Pennsylvania & 30.4 & Mississippi & 36.9 & Alabamo & 32.9 \\
\hline 12 & Georgio & 30.8 & Connecticut & 35.1 & Texas & 33.0 \\
\hline 13 & Texas & 31.3 & Californio & 34.1 & Georgia & 34.1 \\
\hline 14 & Onio & 32.8 & Texas & 31.9 & Connecticut & 34.7 \\
\hline 15 & Alabama & 34.1 & Georgia & 29.9 & Tennessee & 35.1 \\
\hline 16 & Connecticut & 34.3 & Missouri & 26.3 & Wisconsin & 35.4 \\
\hline 17 & Tennessee & 36.5 & Florida & 26.1 & Onio & 38.8 \\
\hline 18 & Arkansas & 37.1 & Indiano & 23.3 & Missouri & 39.6 \\
\hline 19 & Missouri & 37.5 & Wisconsin & 20.5 & Florido & 40.1 \\
\hline 20 & Massochusetts & 39.7 & Ohio & 18.3 & South Carolina & 40.9 \\
\hline 21 & South Carolina & 39.7 & Massachusetts & 17.0 & Arkansas & 42.3 \\
\hline 22 & Rhode Island & 40.2 & South Carolina & 17.0 & Massochusetts & 43.2 \\
\hline 23 & Virginia & 44.3 & Okahoma & 14.5 & New Mexico & 43.9 \\
\hline 24 & Florida & 44.6 & Virginia & 12.7 & Virginio & 45.5 \\
\hline 25 & New Mexico & 45.0 & Arizona & 12.3 & Arizono & 46.9 \\
\hline 26 & Minnesota & 46.1 & Nevada & 7.5 & Indiano & 47.2 \\
\hline 27 & Arizona & 46.9 & Arkansas & 7.2 & Rhode Island & 47.2 \\
\hline 28 & Indiana & 49.7 & North Carolina & 7.1 & Oklahoma & 47.4 \\
\hline 29 & Colorado & 49.8 & New Mexico & 6.4 & North Carolina & 49.2 \\
\hline 30 & North Carolina & 51.5 & Rhode istand & 6.1 & Colorado & 51.0 \\
\hline 31 & Oklahoma & 54.2 & Konsas & 5.2 & Nevada & 52.1 \\
\hline 32 & Nevado & 59.8 & Montana & 1.6 & Minnesoto & 53.9 \\
\hline 33 & Kansas & 60.4 & Delaware & 0.9 & Kansas & 56.2 \\
\hline 34 & Nebraska & 66.7 & Washington & 0.8 & Nebraska & 60.1 \\
\hline 35 & Oregon & 67.5 & Colorado & 0.4 & Oregon & 60.6 \\
\hline 36 & Washington & 70.5 & Minnesota & 0.4 & Washington & 61.2 \\
\hline 37 & West Virginia & 90.3 & North Dakota & 0.1 & Deloware & 63.0 \\
\hline 38 & lowa & 91.5 & Utah & 0.1 & Kentucky & 70.5 \\
\hline 39 & Utah & 91.8 & lowa & 0 & lowo & 74.9 \\
\hline 40 & Kentucky & 92.0 & Kentucky & 0 & West Virginio & 78.7 \\
\hline 41 & Delaware & 93.1 & Maine & 0 & Utah & 80.5 \\
\hline 42 & Montana & 94.2 & Nebraska & 0 & Wyoming & 81.1 \\
\hline 43 & Wyoming & 95.6 & New Hompshire & 0 & Montana & 85.9 \\
\hline 44 & South Dakota & 99.0 & Oregon & 0 & South Dakota & 86.8 \\
\hline 45 & North Dakoto & 99.7 & South Dakota & 0 & North Dakota & 88.7 \\
\hline 46 & Maine & 100.0 & Vermont & 0 & New Hampshire & 93.3 \\
\hline 47 & New Hampshire & 100.0 & West Virginia & 0 & Maine & 94.5 \\
\hline 46 & Vermont & 100.0 & Wyoming & 0 & Vermont & 95.5 \\
\hline
\end{tabular}


Table 2

Change in the Sogregation of Black Students, 1989-94

Stote Rankings on Threo Measures

\begin{tabular}{|c|c|c|c|c|c|c|}
\hline Ronk & $\begin{array}{l}\text { \% in Majorthy } \\
\text { Whithe Schools }\end{array}$ & & $\begin{array}{l}\% \text { in } 90-100 \% \\
\text { Minorthy Schools }\end{array}$ & & $\begin{array}{l}\text { \% Whites in School } \\
\text { of Tripical Block }\end{array}$ & \\
\hline 1 & Minnesoto & -15.2 & Maryland & 12.5 & Nevada & -12.1 \\
\hline 2 & Nevado & -14.5 & Nevada & 7.5 & Minnesoto & -7.0 \\
\hline 3 & Rhode island & -12.8 & Massachusetts & 5.4 & Rhode island & -6.8 \\
\hline 4 & Avizona & -11.1 & Ohio & 5.2 & Wisconsin & -5.7 \\
\hline 5 & Kansas & -7.6 & Louisiana & 4.3 & Florida & -3.7 \\
\hline 6 & Colorodo. & -7.5 & Alabama & 3.7 & Deloware & -3.6 \\
\hline 7 & Nebraska & -7.3 & Rhode island & 3.5 & Nebraska & -3.5 \\
\hline 8 & North Carolina & -6.1 & Wisconsin & 2.7 & Oklahoma & -3.5 \\
\hline 9 & Utan & -6.0 & Florida & 2.6 & Ohio & -3.2 \\
\hline 10 & New Mexico & -5.2 & Texas & 2.1 & Utan & -3.2 \\
\hline 11 & Arkansas & -5.0 & Okahoma & 2.0 & Mamiand & -3.1 \\
\hline 12 & Florido & -4.7 & Michigan & 1.6 & Colorado & -3.1 \\
\hline 13 & Texas & -4.6 & Dist. of Columbia & 1.5 & Arizona & -2.9 \\
\hline 14 & Collfornia & -4.0 & Pennsylvania & 1.5 & Washington & -2.9 \\
\hline 15 & Alabama & -3.7 & Mlinois & 1.3 & Texas & -2.8 \\
\hline 16 & Louisiano & -3.7 & North Carolina & 0.9 & Arkansos & -2.7 \\
\hline 17 & Onio & -3.7 & Delaware & 0.9 & Louisiana & -2.7 \\
\hline 18 & Oldahomo & -3.6 & Washington & 0.8 & Kansas & -2.5 \\
\hline 19 & Maryland & -3.2 & Colorado & 0.4 & Vermont & -2.3 \\
\hline 20 & Mississippi & -3.1 & Minnesoto & 0.4 & Alabama & -2.2 \\
\hline 21 & Indiana & -3.1 & Mississippi & 0.1 & New Mexico & -2.2 \\
\hline 22 & lowa & -3.0 & Kentucky & 0.0 & lowo & -2.1 \\
\hline 23 & Wisconsin & -2.9 & Nebraska & 0.0 & North Carolina & -2.0 \\
\hline 24 & Connecticut & -2.6 & New Hampshire & 0.0 & Californiםి & -1.9 \\
\hline 25 & South Carolina & -2.4 & Oregon & 0.0 & Mississippi & -1.8 \\
\hline 26 & New York & -2.0 & Utan & 0.0 & Kentucky & -1.7 \\
\hline 27 & Kentucky & -1.3 & Vermont & 0.0 & Massachusetts & -1.4 \\
\hline 28 & Tennessee & -1.0 & West Virginio & 0.0 & South Carolina & -1.1 \\
\hline 29 & Pennsytvania & -0.8 & New Mexico & -0.1 & Pennsylvania & -0.8 \\
\hline 30 & Massachusetts & -0.8 & South Carolina & -0.3 & Connecticut & -0.8 \\
\hline 31 & Deloware & -0.2 & North Dakota & -0.3 & Tennessee & -0.6 \\
\hline 32 & Michigan & -0.1 & Now York & -0.3 & New York & -0.6 \\
\hline 33 & Dist. of Columbia & 0.0 & California & -0.5 & Michigan & -0.3 \\
\hline 34 & New Hampshire & 0.0 & New Jersey & -0.8 & Illinois & -0.1 \\
\hline 35 & Vermont & 0.0 & Tennessee & -0.8 & Dist. of Columbia & -0.1 \\
\hline 36 & North Dakota & 0.4 & lowa & -0.8 & New Jersey & 0.0 \\
\hline 37 & 诮inois & 0.4 & Arizono & -1.2 & West Virginio & 0.0 \\
\hline 38 & Washington & 0.4 & Kansas & -1.4 & New Hampshire & 0.3 \\
\hline 39 & New Jersey & 0.5 & Connecticut & -1.9 & Indiana & 0.4 \\
\hline 40 & West Virginio & 1.4 & Avkansas & -2.2 & North Dakota & 1.9 \\
\hline \multirow[t]{7}{*}{41} & Oregon & 5.7 & Indiana & -4.4 & Oregon & 19.6 \\
\hline & Georgia & • & Georgia & $\cdot$ & Georgia & • \\
\hline & Maine & • & Maine & $\cdot$ & Maine & • \\
\hline & Missouri & • & Missouri & $\cdot$ & Missouri & * \\
\hline & Montana & $\cdot$ & Montana & • & Montano & 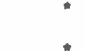 \\
\hline & South Dakota & " & South Dokoto & $"$ & South Dakota & . \\
\hline & $\begin{array}{l}\text { Virginia } \\
\text { Wyoming }\end{array}$ & . & $\begin{array}{l}\text { Virginio } \\
\text { Wyoming }\end{array}$ & 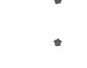 & $\begin{array}{l}\text { Virginic } \\
\text { Wyoming }\end{array}$ & - \\
\hline
\end{tabular}

"These states did noi report school enioliments by race to NCES for the 1989-90 school year. 


\section{NOTES}

1. Distribution of Latinos by ethnicity and state is reported in M. Beatriz Arias, "The Context of Education for Hispanic Students: An Overview;" American Journal of Education 95(1) (November 1986): 26-57.

2. In this report "white" means non-Hispanic whites. Hispanic or Latino is treated as part of the non-white population although many Latinos define themselves as whites in racial terms. These definitions are used to avoid the awkward and confusing language that would otherwise be necessary and is not an attempt to define Latinos as a race.

3. U.S. Bureau of Census Projections, Steven A. Holmes, "Census Sees a Profound Ethnic Shift in U.S.," New York Times, March 14, 1996; Education Week, March 27, 1996, p. 3.

4. Gary Orfield, "Public Opinion and School Desegregation," Teachers College Record 96(4) (Summer 1995); Gallup Poll in USA Today, May 12, 1994; Gallup Poll in Phi Delta Kappan, September 1996. The 1996 survey reported that "the percentages who say integration has improved the quality of education for blacks and for whites have been increasing steadily since these questions were first asked in 1971"(p. 48). The report also showed that $83 \%$ of the public believed that interracial schools were desirable.

5. 402 U.S. 1 (1971).

6. Keyes v. Denver School District No. 1, 413 U.S. 189 (1973).

7. 418 U.S. 717 (1974).

8. Calculations of metropolitan segregation from 1992 Common Core data.

9. 433 U.S. 267 (1977).

10. 115 S.Ct. 2038 (1995).

11. 498 U.S. 237 (1991).

12. 503 U.S. 467 (1992).

13. Ruben Espinosa and Alberto Ochoa, "Concentration of California Hispanic Students in Schools with Low Achievement: A Research Note," American Journal of Education 95(1), (1986): 77-95; Ruben Donato, Martha Menchaca, and Richard R. Valencia, "Segregation, Desegregation, and the Integration of Chicano Students: Problems and Prospects" in Richard R. Valencia, ed., Chicano School Failure and Success: Research and Policy Agendas for the 1990s (London: Falmer Press, 1991): 2763.

14. A national survey by the Boston Globe in 1992 reported that $82 \%$ of Latinos said that they favored busing if there was no other way to achieve integration and that Latinos expressing an opinion said that they would be "willing to have your own children go to school by bus so the schools would be integrated" ("Poll Shows Wide Support Across U.S. for Integration," Boston Globe, January 5, 1992: 15); for evidence of more closely divided opinion earlier see Gary Orfield, "Hispanic Education: Challenges, Research, and Policies, "American Journal of Education 95(1)(1986): 11-12.

15. Almost two-thirds of Latino students are of Mexican origin (Arias, 1986-see note 1).

16. See, for example, discussion of the relationship of disadvantaged school status and educational opportunity in Jeannie Oakes, Multiplying Inequalities: The Effects of Race, Social Class, and Tracking on Opportunities to Learn Mathematics and Science (Santa Monica: RAND, 1990), figure 2.3.; 1988 NAEP data reported in Educational Testing Service, The State of Inequality; Peter Scheirer, "Poverty not Bureaucracy," Working
Paper, Metropolitan Opportunity Project, Univ. of Chicago, 1989; Samuel S. Peng, Margaret C. Wang, and Herbert J. Walberg, "Demographic Disparities of Inner-City Eighth Graders," Urban Education 26(4) (January 1992): 441-459; David M. Cutler and Edward L. Glaeser, "Are Ghettos Good or Bad?" (Cambridge: National Bureau of Economic Research, 1995): Gary G. Wehlage, "Social Capital and the Rebuilding of Communities," Center on Organization and Restructuring of Schools, Issue Report No. 5, Fall 1993: 3-5; Raymond Hernandez, "New York City Students Lagging in Mastery of Reading and Math," New York Times, January 3, 1997: A1, B4; a 1997 study in the suburban Washington district of Prince George's County reported that "with each 10 percent increase in the number of students who qualified for free or reduced-price lunches, a school's score on the state test dropped by an average of 1.8 percentage points in reading, 4.1 percentage points in math and 2.2 percentage points in science" (Washington Post, May 15, 1997: A17).

17. A study of 1992 test scores in greater Cleveland showed that district poverty level differences "explained as much as 39 percent of the differences in school district passing rates" on the state proficiency test (Cleveland Plain Dealer, Oct. 8, 1995. 3-C).

18. Asian students, who are having far greater success in U.S. schools, attend schools that average only about onefourth African American and Latino students and they are far less likely to be in high poverty schools, factors that help account for their mobility (Asian Students and Multiethnic Desegregation, Harvard Project on School Desegregation, October 1994).

19. Keyes v. School District No. 1, Denver Colorado, 1973.

20. A recent Gallup Poll showed that $93 \%$ of the public and $96 \%$ of school parents thought it was very important to teach students "acceptance of people of different races and ethnic backgrounds" (Phi Delta Kappan, October 1993: $139,145)$.

21. Interviews with Assistant Secretary Norma Cantu and Acting Assistant Attomey General Isabel Pinzler, March 18, 1997.

22. A New York Times analysis of the 4,100 schools in the state reported, for instance, that all ten of the weakest third grade reading achievement scores were in New York City public schools, four of which had $99 \%$ or more poor children and only one of which had a majority of children not on free lunch. The analysis showed an extremely strong relationship between poverty and achievement. City schools with totally low income enrollments had an average of less than a fifth of children reading above grade level, while schools with no low: income children in the city had about $75 \%$ scoring above grade level ("Rating the Schools: Best Report Cards, and Worst," New York Times, January 3, 1997: B4; "Beyond Wealth and Poverty: About the Adjusted Scores," Ibid.: B5); the 1997 federally sponsored report to Congress on Title I concluded that "school poverty depresses the scores of all students in schools where at least half of the students are eligible for subsidized lunch." (Education Week, March 16, 1997: 23).

Gary Orfield is Professor of Education and Social Policy at Harvard Graduate School of Education and the John F. Kennedy School of Government. 
Mark D. Bachmeier is a Ph.D. candidate in sociology at Indiana Liniversity, Bloomington. He is currently conducting dissertation research on equality in the funding of U.S. public schools and collaborating with David R. James on a study of trends in public school segregation in metropolitan areas of the United States from 1970 to 1990.

David R. James is Associate Professor of Sociology at Indiana University, Bloomington. His current research fo- cuses on equity issues in public school finance and the racial assignment of public and private school students in the United States between 1970 and 1990.

Tamela Eitle is a Ph.D. candidate in sociology at Indiana University, Bloomington. She is completing her dissertation research on the causes and consequences of racial segregation within schools. 